different types of communities, and the necessity for them to make a socio-cultural choice in situation of scientific and technological achievements and transformations. Purpose. The aim of the study is to identify the socio-cultural aspects of social and philosophical thinking based on the analysis of modern approaches to social globalization changes. Methods. The research is based on the methods of sociocultural analysis of social reality and reinterpretation of the theoretical achievements of modern social thinkers on the basis of the principles of objectivity, historicity, inter-subjectivity. Originality. That is, scientific and technological development will contribute to realization of ideals of freedom and justice or promote the realization of consumer values and individualism. It will also influence on the approval of foundations of a new social-philosophical thinking aimed at both the identification of crisis situations and challenges, and the transformation them into the points of socio-cultural renewal. This is especially true of our Ukrainian socio-cultural reality and society as a whole which finds oneself in the situation of an important civilization breakdown, socio-cultural paradoxes, crisis of social identity and formation of forms of public society. Conclusion. In this study the social -philosophical thinking is considered as such one which is aimed at real maintenance of constitutive factors of any social community through the identification of interdependences and interrelationships. It is also a necessary factor of the mechanism of social interaction and a peaceful instrument of social order, and a factor of realization of integrate needs of a person and a whole society as well. Thus, social-cultural reception of the phenomenon of socialphilosophical thinking is aimed at preserving of socio-constructive potential under the modern conditions of global risks and dangers.

Key words: social-philosophical thinking, social identity, social reality, socio-cultural choice, social-cultural space.

Одержано редакиією 17.03.2018

Прийнято до публікації 11.06.2018

УДК 172:007.51

DOI: 10.31651/2076-5894-2018-1-41-46
HONCHARENKO Valeria Anatoliivna,

Post-graduate student of the Department of Philosophy and Religious Studies, Bohdan Khmelnytsky National University of Cherkasy, e-mail: qj14918@gmail.com

\title{
ETHICS OF INFORMATION BY LUCIANO FLORIDI - PROBLEM OF INFORMATIONAL PRIVACY AND MORALITY OF ARTIFICIAL AGENTS
}

\begin{abstract}
Introduction. The article tackles the concept of IE (information ethics), the fundamental principles of IE and its place in the contemporary philosophical discourse by Luciano Floridi which are being represented in his publication "The Ethics of Information" (2013). The purpose of the article is to elucidate the major characteristics of information ethics, to analyze the interconnection between ethics and concept of information, to consider the problems of the informational privacy and the morality of artificial agents as one of the most challenging issues which are indicated as an important part of the IE research as well. To achieve the aim mentioned above we apply the methods of comparative analysis, methods of the hermeneutic reconstruction and reinterpretation, analytical and synthetic methods. Based on the latest investigations and critical reviews it should be stressed that ethics was always considered a strictly human business and it has experienced a methodological crisis along with the whole philosophical discourse as well. As the major practical discipline, ethics deals with the ambivalent nature of human existence, its daily troubles and deepest concerns on how to be a human, its vision of the Self as a subject of a moral action and duty, therefore it regulates adequacy of norms of human behavior in society turning moral conventional norms into a law for the benefits of all. However, it should be noted that the sphere of ethical research is not restricted to human matter anymore, morality can also be extrapolated on artificial agents, an
\end{abstract}


approach to ethics can be re-formulated in order to adjust it to the demands of the informational age. Information ethics (IE) can be a crucially helpful field of research with handling digital information, identity theft, informational privacy, cyber war, computing devices and developing artificial intelligence. Conclusion. After reviewing the topics mentioned above it is necessary to mention that computer science and its technological applications influenced the world's progress in social communication, media studies, cultural life and sphere of economy, in other words, a contemporary scientific picture of the world was transformed by ICTs. Ethics is supposed to be at the center of informational operations, digital information processing, furthermore, IE (information ethics) can regulate the informational flow in different ways based on its renewed principles. Due to the exponential increase in common knowledge (Luciano Floridi), information can be a dangerous tool used for wrong purposes which make IE more relevant than ever because everyone should share a responsibility for the world we live in.

Key words: Luciano Floridi, information ethics (IE), ICTs, informational privacy, artificial agent.

Formulation of the problem. Interest in the problem is determined by the necessity of the upgrade of ethics, a transformation of its principles, the inclusion of its conceptions into the informational process and its regulation. In addition, ethics as an ethics of the information can be capable of producing new concepts on how to be moral and preserve commonly shared values in the digital era.

Analysis of the recent research and publications. Among the latest publications and investigations devoted to the issues such as the ethics of information, the role of philosophy in a digital world and its conceptual approximation to the ICTs should be noted: "The Ethics of Information" by Luciano Floridi (2013), "Protection of Information and the Right to Privacy A New Equilibrium?" by Luciano Floridi (2016), "Ethics in Information Technology" by George Reynolds (2014), "Information Ethics: Privacy, Property, and Power" by Adam Daniel Moore (2005), "Ethical Principles for the Information Age" by Richard Severson (1997), "Quinn: Ethics for the Information" by Michael J. Quinn (2016), "Cyberethics: Morality and Law in Cyberspace" by Richard Spinello (2016), "World without mind: The Existential Threat of Big Tech" by Franklin Foer (2017), "Machine, Platform, Crowd: Harnessing Our Digital Future" by Andrew McAfee (2017), "The Second Machine Age: Work, Progress, and Prosperity in a Time of Brilliant Technologies" by Erik Brynjolfsson (2016), "The Digital Mind: How Science Is Redefining Humanity" by Arlindo Oliveira (2017), "Common Sense, the Turing Test, and the Quest for Real Al" by Hector J. Levesque (2017), "Shaping a Digital World: Faith, Culture and Computer Technology" by Derek C.Schuurman (2013), "Thinking Machines: The Quest for Artificial Intelligence - and Where It's Taking Us Next" by Luke Dormeht (2017), "Deep Thinking: Where Machine Intelligence Ends and Human Creativity Begins" by Garry Kasparov (2017), "The Industries of the Future" by Alec Ross (2017), "The New Digital Age: Transforming Nations, Businesses, and Our Lives" by Eric Schimdt and Jared Cohen "(2013), classic work "Can machines work?" by Alan Turing (1950) and many others.

Purpose. The major task of our article is to analyze the fundamentals of the ethics of information, to distinguish the specific features of ICTs and ethics of information and to present arguments of its correlation, to outline the perspective and relevance of research on the ethics of information, based on the above-mentioned publication.

Presenting the main material. To begin with, it is necessary to stress that information ethics (IE) is determined by fundamental informational changes of our historical time. Based on this statement, the following concept cannot be correctly interpreted without a proper explication of its comprehension of the history. "No records, no history: so history is actually synonymous with the information age since pre-history is that age in human development that precedes the availability of recording systems" [1, p. 3]. According to Luciano Floridi's interpretation, our historical stage can be defined as a hyperhistory or a hyperhistorical predicament. Basically, it means that the prosperity of society and the human progress in general depend on efficient management of the life-cycle of information. Thereby, "the life cycle of information typically includes the following phases: 
occurrence (discovering, designing, authoring, etc.), recording, transmission (networking, distributing, accessing, retrieving, etc.), processing (collecting, validating, merging, modifying, organizing, indexing, classifying, filtering, updating, sorting, storing, etc.), and usage ( monitoring, modeling, analyzing, explaining, planning, forecasting, decision-making, instructing, educating, learning, playing, etc.) [2, p. 5-6]. ICTs profoundly transformed the human environment into an infosphere which relates to the informational ontology and can be denoted as the synonym of being or reality in informational terms. Accordingly, the philosopher emphasizes the necessity of reconceptualization and re-ontologizing of the infosphere. "The most obvious way in which ICTs are re-ontologizing the infosphere concerns the transition from analogue to digital data and then the ever-increasing growth of our informational space" [1, p. 7]. In addition, Luciano Floridi argues that the new focus for philosophy must be information-oriented due to the rapid development of digital technologies." Virtual reality is essentially plastic; abstracted from physical reality, it is free from the harsh necessities of stuff that have the tendency to conflict with our desires and actions" [3, p. 28]. Thus, informational ontology and information ethics have more advantages in regards to regulations where we can escape routine Kantian conflicts of duty and desire.

Information ethics (IE) is positioned as is a branch of philosophy of information that investigates, in a broad sense, the ethical impact of Information and Communication Technologies (ICTs) on human life and society as Luciano Floridi states. "Thus, IE, understood as an ethics of informational products, covers moral issues arising, for example, in the context of accountability, liability, libel legislation, testimony, plagiarism, advertising, propaganda, misinformation, disinformation, deception, and more generally of pragmatic rules of communication a la Grice [1, p. 23]. Accordingly, the major concern of IE is how any information is being handled, managed and interpreted. Dealing with information like with something morally questionable is becoming one of biggest necessities of humanity because all the facts that take place must be seen and analyzed through an ethical point of view. "This professional convergence, driven by the growth of Internet and digital access, shifts emphasis, but there is a core of intellectual freedom issues, privacy and secrecy, concerns with social equity and justice and matters of the ownership of information that show differing faces across all of the domains" [4, p. 241].Henceforth, interdisciplinary fields of research and institutions recognized the importance of ethics because the inability to solve most social problems is deeply rooted in ethical sphere.

It should be noted that IE is a patient-oriented ethics which means that it is a rights-based approach that proscribes the using of another's body, talent, labour for the benefit of the other. The following theory states that "the receiver of the moral action may be not only a human being, but also any form of life" [1, p.62]. Furthermore, "a patient-oriented ethics holds the broad view that any form of life has some essential proprieties or moral interests that deserve and demand to be respected, at least initially, minimally, and overridably" [1, p. 63]. It indicates the originality and autonomy of any form that generates life, in addition, it is directed to the entity (patient) that embraces the action which expands the limits of the ethical research without being attached to the agent of moral action and his subjectivity.

One of the moral questions within IE research is what is good for an informational entity and the infosphere in general? To provide us with the answer, philosopher argues that "any informational entity is recognized to be the centre of some basic ethical claims that deserve recognition and should help to regulate the implementation of any information process involving it" $[1$, p. 70$]$. As a result, criteria that define what is right or wrong and so on are conditioned by four basic ethical principles such as 1) entropy ought not to be caused in the infosphere (null law) 2) entropy ought to be prevented in the infosphere 3) entropy ought to be removed from the infosphere 4) the flourishing of informational entities as well as of the whole infosphere ought to be promoted by preserving, cultivating, and enriching their well-being according to Luciano Floridi's conception. Term "entropy" is interpreted as a metaphysical one that refers to any form of an impoverishment of being according to thinker's position. 
Addressing the question about the IE as a macroethics, it should be stressed that "IE is not an ethics of virtue, happiness, or duty, but of 'respect' for the patient and 'care' exercised by the agent. According to IE, sometimes the right question to be asked is not 'what ought I to be?' nor 'what ought I to do?', but 'what ought to be respected or improved?', for it is the 'what's' wellbeing that may matter most" [1, p. 74]. It should be particularly noticed that Luciano Floridi presents IE as a universal ethical approach that attempts to produce new moral claims within the open informational system. In regards to the understanding of altruism, it should be mentioned that any action can be considered moral or good only if it was determined by the care for a patient and his or her well-being. Finally, the similarity between EI and virtue ethics is that these theories represent an individual as a subject of permanent change, a self-project that is building up a personality through a short lifetime. But "the difference between the two approaches lies in their ontologies and in the much broader conception of what may count as a good entity endorsed by IE" [1, p. 77]. Accordingly, the information is placed at the center of informational transactions and possesses a value that has a right to be acknowledged.

The issue of the informational privacy is considered to be one of the most critical problems nowadays. When we talk about a person's identity, a digital identification takes an attributive place in the whole entity that a person identifies as himself or herself. If a digital personality and all the information that constitute him/her as such is such a pivotal matter, it is ought to be properly protected. Hence, a philosopher states that "informational privacy is a function of the ontological friction in the infosphere" [1, p. 232]. Basically, a breach of someone's privacy is a violation, a form of aggression towards a personal identity. There are a lot of ways of misuse of information that can affect personal rights, public life and future. In the space of informational totality it is significant to remember about the right to be recognized and the right to be forgotten. Thus, personal data thanks to IE and its regulations can be protected from intrusion and anonymous interference such as PITs (Privacy Intruding Technologies) within the space of its accessibility."In the re-ontologized infosphere, any information agent has an increased power not only to gather and process personal data but also to control and protect them" [1, p. 236]. ICTs made common societal interactions more transparent but it does not necessarily mean that it has drastically changed from the old days. Technological advancement does not put everyone under more serious threat and risk to be discredited but it is everyone's responsibility to empower ourselves at keeping our personal data as private as possible. It is up to us to choose what helps us feel more secure. "Informational privacy is a utility, also in the sense of providing an essential condition of possibility of good human interactions, e.g. by preserving human dignity or by providing political checks and balances" [1, p. 240-241].

On the whole, this issue can be addressed in the several contexts such as active and passive types. "Actively, because collecting, storing, reproducing, manipulating, etc. one's information amounts now to stages in stealing, cloning or breeding someone else's personal identity. Passively, because breaching one's informational privacy may now consist in forcing someone to acquire unwanted data, thus altering her or his nature as an informational entity without consent" $[1$, p. $243-$ 44]. It should be noted that people must be more equipped with tools that keep their private data safe because of new informational challenges such as identity theft, child pornography, the leak of personal info from social networks and its unauthorized usage, hacker attacks, revenge porn, fake news, cyberharassment and other. Consequently, it is understood that breach of informational privacy has to be as equally illegal and prosecuted by law as human trafficking, drug trade, murder or other crimes.

Concerning the morality of artificial agents, it should be said that not all the agents operating within the infosphere are necessarily moral but they can be if humans build them to be that way. "When moral artificial agents are in question, what counts is their moral accountability" [1, p. 135]. An accountability does not depend on the state of mind and to defend this view Luciano Floridi uses the term "mindless morality". Being accountable can also have a moral impact and cause "artificial 
good" or "artificial evil". Furthermore, "machines that are both autonomous and beneficent will require some kind of moral framework to guide their activities" [5, p. 58]. It is quite uncertain how humans will program machines to be friendly in terms of conventionally accepted behavior but there is an urgency to explore and question the results. Using the right LoA (level of abstraction), there are three criteria to follow for any agent: 1) interactivity 2) autonomy 3) adaptability. Thereby, "an action is said to be morally qualifiable if and only if it can cause moral good or evil, that is, if it decreases or increases the degree of metaphysical entropy in the infosphere" [1, p. 147]. It means that the agent who intends to act, must be profound and aware of consequences that involved in a specific action, otherwise, the agent cannot be qualified as a moral one. It applies to all kinds of entities, including humans, groups, companies, AAs (artificial agents) and many other. Referral to the LoA formalizes the accountability and responsibility and liberates it from anthropocentric attitudes which are significant advantages for the contemporary ethical discourse. "Promoting prescriptive action is perfectly reasonable even when there is no responsibility but only moral accountability due to the capacity for moral action" [1, p. 159].

Ultimately, it should be mentioned that patient-oriented or non-standard approach brings the ethical field of research to the new level of discussion because it expands the horizon of entities which are inclined in activity where moral actions can be exercised.

Conclusion. Summing up, it should be outlined that IE (information ethics) is called to produce new moral claims and regulations determined by the challenges of the digital era. Because the informational gap between technology and ethical theory deepens on daily basis, anthropocentric ethics cannot handle tasks that involve artificial agents using the methods that are restricted to human matter. Ethics must be transformed to be able to respond to fake news, identity theft, unauthorized access of personal information and its misuse, revenge porn, cyberwar, hacking, copyright and intellectual property protection etc. It should be noted that virtual reality must be examined by ethical point of view because all the members of the informational community must be accountable. Informational privacy is ought to be a priority of IE research. Negligence towards the privacy of information can lead not just to a personal tragedy but to total abuse of all information sources available that true and false, right and wrong will no longer have validation. Privacy must have not only legislative dimension but an informational one too. Above all, an individual does not identify himself or herself without social accounts, social networks, devices and all the information that literally constructs his or her digital identity. In regards to morality of artificial agents, it should be mentioned that not all of them are going to be moral but they can be accountable. Liberation of artificial entities from human business is essential, as it expands the field of ethical competency and pushes humanity to produce alternative answers to pressing issues of our informational societies. The following approach does not reject the concept of responsibility as unsubstantial but gives it a new understanding in the informational terms.

\section{References (in language original)}

1. Floridi L. The Ethics of Information / Luciano Floridi. - Oxford University Press, 2013. - 357 p.

2. Floridi L. The Fourth Revolution: How the Infosphere is Reshaping Human Reality / Luciano Floridi. - Oxford University Press, 2014. - 248 p.

3. Crawford M. Virtual Reality as Moral Ideal / Matthew Crawford / The New Atlantis. - 2015. - \# 44. - P. 28-36.

4. Sturges P. Information Ethics in the Twenty First Century / Paul Sturges / Australian Academic \& Research Libraries. - 2009. - \# 40(4). - P. 241-251.

5. Rubin C. Machine Morality and Human Responsibility / Charles Rubin / The New Atlantis. - 2011. - \# 32. - P. 58-79.

\section{References}

1. Floridi, L. (2013). The Ethics of Information. Oxford University Press.

2. Floridi, L. (2014). The Fourth Revolution: How the Infosphere is Reshaping Human Reality. Oxford University Press.

3. Crawford, M. (2015). Virtual Reality as Moral Ideal. The New Atlantis, 44, 28-36.

4. Sturges, P. (2009). Information Ethics in the Twenty First Century. Australian Academic \& Research Libraries, 40(4), 241-251.

5. Rubin, C. (2011). Machine Morality and Human Responsibility. The New Atlantis, 32, 58-79. 


\section{ГОНЧАРЕНКО Валерія Анатоліївна,}

аспірантка кафедри філософії та релігієзнавства

Черкаського національного університету

імені Богдана Хмельницького,

e-mail: qj14918@gmail.com

\section{ЕТИКА ІНФОРМАЦІЇ ЛУЧАНО ФЛОРІДІ - ПРОБЛЕМА ІНФОРМАЦИЙНОЇ ПРИВАТНОСТІ ТА МОРАЛЬНІСТЬ ШТУЧНИХ АГЕНТІВ}

Анотація. Статтю присвячено розгляду ключових ідей інформачійної етики Лучано Флоріді, зокрема проблеми інформаиійної приватності та моральності штучних агентів. Експліковано та проаналізовано провідні принципи IE (інформаційна етика), виявлено кореляцію між етикою та концептом інформації. Закцентовано увагу на співвідношенні філософії та IKT (інформаційнокомунікаційні технології), ̈̈х ролі у прочесі самоідентифікаиії людини та парадигмальній зміні наукової картини світу. Доведено релевантність проблеми інформаційної приватності, щяо є однією із найголовніших концепчій у сфері досліджень IE. Окреслено питання моральності штучних агентів та наголочено на методологічному переході від антропоцентричної етики до алоиентричного підходу у сфері етичних досліджень. Особливу увагу звернуто на принципово відмінний підхід IЕ до класичної етичної проблематики та шляхи подолання кризового стану етичної рефлексії.

Ключові слова: Лучано Флоріді, інформачійна етика (IE), IKT, інформаційна приватність, штучний агент. 